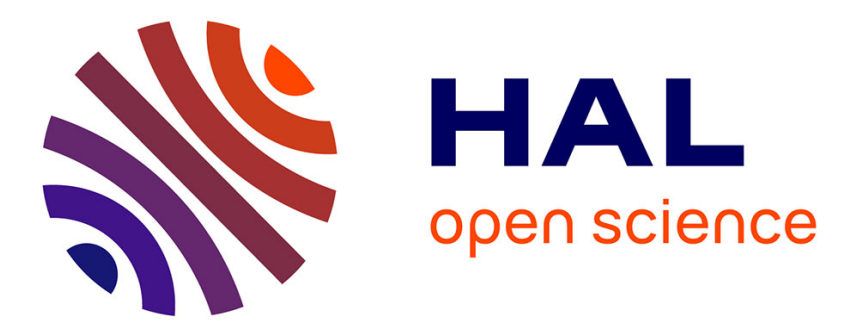

\title{
Access to 3-Oxindoles from Allylic Alcohols and Indoles
}

Hortense Lauwick, Yang Sun, Huriye Akdas-Kilig, Sylvie Dérien, Mathieu

Achard

\section{To cite this version:}

Hortense Lauwick, Yang Sun, Huriye Akdas-Kilig, Sylvie Dérien, Mathieu Achard. Access to 3Oxindoles from Allylic Alcohols and Indoles. Chemistry - A European Journal, 2018, 24 (31), pp.79647969. 10.1002/chem.201800348 . hal-01834006

\section{HAL Id: hal-01834006 \\ https://hal-univ-rennes1.archives-ouvertes.fr/hal-01834006}

Submitted on 13 Jul 2018

HAL is a multi-disciplinary open access archive for the deposit and dissemination of scientific research documents, whether they are published or not. The documents may come from teaching and research institutions in France or abroad, or from public or private research centers.
L'archive ouverte pluridisciplinaire HAL, est destinée au dépôt et à la diffusion de documents scientifiques de niveau recherche, publiés ou non, émanant des établissements d'enseignement et de recherche français ou étrangers, des laboratoires publics ou privés. 


\title{
Access to 3-oxindoles from Allylic Alcohols and Indoles
}

\author{
Hortense Lauwick, ${ }^{[a]}$ Yang Sun, ${ }^{[a]}$ Huriye Akdas-Kilig, ${ }^{[a]}$ Sylvie Dérien ${ }^{[a]^{*}}$ and Mathieu Achard ${ }^{[a]^{*}}$
}

\begin{abstract}
The site and regioselective allylation reaction of 2 substituted indoles was carried out by using a ruthenium(IV) precatalyst containing phosphine-sulfonate chelate. Mono-, di- and tri-allylated indoles could be selectively obtained according to reaction conditions and gave only water as byproduct. The preparation of 3-oxindole derivatives was then successfully performed owing to the oxidation under air of the corresponding allylated indoles. Diallylated pseudoindoxyls were proved to be good synthons to perform cyclization through Ring Closing Metathesis affording the corresponding tricyclic adducts. Photophysical properties of 3-oxindoles have been measured, some compounds showing a strong fluorescence in water.
\end{abstract}

\section{Introduction}

Pseudoindoxyl derivatives containing the indolin-3-one core structure and a quaternary stereogenic center at the 2-position is an attractive class of compounds with highly interesting photophysical or biological properties (Figure 1). ${ }^{[1,2]}$ They are found in various biomolecules such as the spirocyclic Aristotelone, ${ }^{[1 \mathrm{a}]} \quad$ Brevianamides, ${ }^{[1 \mathrm{~b}]} \quad$ Mytragynine pseudoindoxy|[1c,d] as well as in the Isatisine $A,{ }^{[1 e]}$ Duocarmycin $A, C^{[1 f, g]}$ and Fluorocurine. ${ }^{[1 \mathrm{~h}]}$ Following the seminal observations of Perkin and Plant ${ }^{[3]}$ that 10,11-dihydroxyhexahydrocarbazoles are unstable under basic conditions, reexamination by Witkop demonstrated the formation of the key 3-hydroxyindolenines which undergo a semi-pinacolic rearrangement to afford the corresponding 3-oxindoles. ${ }^{[4]}$ Various oxidative approaches have been described in the literature to access 3-hydroxyindolenines involving the use of strong oxidants such as dimethyldioxirane, ${ }^{[5]}$ meta chloro perbenzoic acid ${ }^{[6]}$ and others. ${ }^{[7]}$ Alternative pathways involve photo-oxygenation of the substituted indoles and the transient formation of hydroperoxides. ${ }^{[8]}$ Alternative approaches to 3-oxindoles are also reported in the literature. ${ }^{[9]}$

Due to the presence of a rigid conjugated electron-donor acceptor fragment Restricting Intramolecular Rotation (RIR), several pseudoindoxyls exhibit fluorescent properties. In 1983, during the isolation of various alkaloids of Aspidosperma oblongum, Potier and al. isolated pseudoindoxyl derivatives as "Produit jaune, amorphe, très fluorescent à l'uv". ${ }^{[1 c]}$ Recently, 3oxindoles have been used as fluorophores (Figure 1).[2] Among them, Lipid green $\circledast$ has been used for the fluorescent labelling of lipid droplets. ${ }^{[2 b, c]}$ Other reports highlight their facile postfunctionalization to tune their photophysical properties. ${ }^{[2 a]}$

[a] Univ Rennes, ISCR (Institut des Sciences Chimiques de Rennes) UMR 6226, F-35000 Rennes, France

E-mail: mathieu.achard@univ-rennes1.fr sylvie.derien@univ-rennes1.fr
Therefore the development of sustainable transformations to access 3-oxindole derivatives minimizing the steps and waste is highly desirable.

Transition metal complexes-catalyzed allylic substitution become a method of choice for the formation of various Carbon-Carbon and Carbon-Heteroatom bonds. ${ }^{[10]}$ In these transformations, the use of dissymmetric allylic substrate raises the control of regioselectivity and several ruthenium precatalysts have shown excellent activities for the formation of branched products. ${ }^{[11]}$ Interestingly, recent developments toward the introduction of an allylic or an alkyl fragment were developed via transition metalcatalyzed allylic substitution, borrowing hydrogen methodology or more recently hydroelementation starting from simple allylic or aliphatic alcohols ${ }^{[12-17]}$ and alkynes or allenes ${ }^{[18]}$ providing an useful atom economical toolbox to access to allylated or alkylated indoles. Recently, some of us reported the synthesis of an allylation ruthenium precatalyst by designing an allylic ruthenium(IV) complex featuring phosphine-sulfonate chelate which proven efficiency in regio- and chemo-selective allylation from various allylic alcohols. ${ }^{[16 j, 19]}$
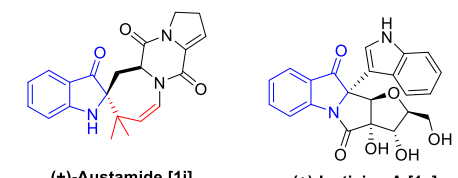

(+)-Austamide [1i]

$$
\text { (+)-Isatisine A [1e] }
$$

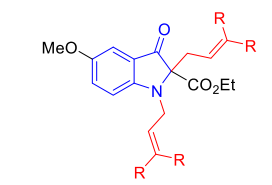

LipidGreen and LipidGreen : LipidGreen and LipidGreen2:
Lipophilic green Fluorescent probes $[2 b, c]$

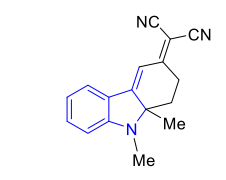
post-functionalized indolin-3-one
red fluorescent organic dye [2a]
Figure 1. Examples of biorelevant or synthetic pseudoindoxyls and applications.

Herein we disclose a facile access to various substituted indole derivatives starting from allylic alcohols via a rutheniumcatalyzed regio- and site-selective allylation followed by a solidstate oxidation on the resulted allylated indoles to afford the corresponding indoxyls generating water as the sole byproduct of the overall reaction sequence.

\section{Results and Discussion}

The allylation of 2-methyl indole $\mathbf{1 a}$ in the presence of catalytic amount of our previously described Ru-1 $\left\{\left[\mathrm{Ru}\left(\mathrm{Cp}^{*}\right)\left(\mathrm{H}_{2} \mathrm{CCHCH}_{2}\right)(\mathrm{dppbs})\right] \mathrm{PF}_{6}\right\}$ was first evaluated (Table 1). ${ }^{[16]]}$ During the stoichiometric treatment of $1 \mathrm{a}$ with allyl alcohol 2a, selective $C(3)$-allylation occurred in dichloromethane in less than three hours reaction time providing 3aa with almost 
complete conversion (entry 1). Increasing the amount of allyl alcohol 2a to 2 equivalents, resulted in the selective $N$ - and $C(3)$-allylation to afford the product 4aa (entry 2). Higher amount of allyl alcohol along with the catalyst loading had a crucial influence on the selectivity and favored the formation of the diallylated compound 4aa (entry 2). 2-methylindoles are useful scaffolds for the generation of 2-vinylindolines and 0 quinodimethanes. ${ }^{[20]}$ However, alkylation of 2-methylindole usually require harsh reaction conditions or the use of strong base such as organolithium reagent or KHMDS to ensure conversion. ${ }^{[20]}$ Astonishingly, this catalytic system was not limited to the $N$ - or $C(3)$ allylation and for the first time, the base free allylation of the methylene moiety was achieved leading to the tri-allylated product 5aa accompanied with traces of the tetraallylated side product (entry 3 ). It is important to note that this last transformation was very sensitive to the reaction conditions and lower selectivity and conversion were observed with lower catalyst loading and/or insufficiently deaerated solvent. Finally, almost complete formation of the tri-allylated indole 5aa was obtained in the presence of 7 mol\% of Ru-1 (entries 4 and 5). Having established our best reaction conditions toward selective allylation, we next examined the scope of the transformation with 2-methylindole 1a and 2-phenyl indole 1b (Scheme 1). As expected, indoles $\mathbf{1 a}$ and $\mathbf{1} \mathbf{b}$ react smoothly with allyl alcohol $\mathbf{1 a}$ leading to the selective formation of mono-allylated products 3aa and 3 ba in up to $90 \%$ isolated yields. In the case of unsymmetrical allylic alcohols, the allylation afforded the branched indoles with complete regioselectivity toward the

Table 1. Ruthenium-catalyzed site-selective allylation of 2-methylindole 1a with allyl alcohol 2a.

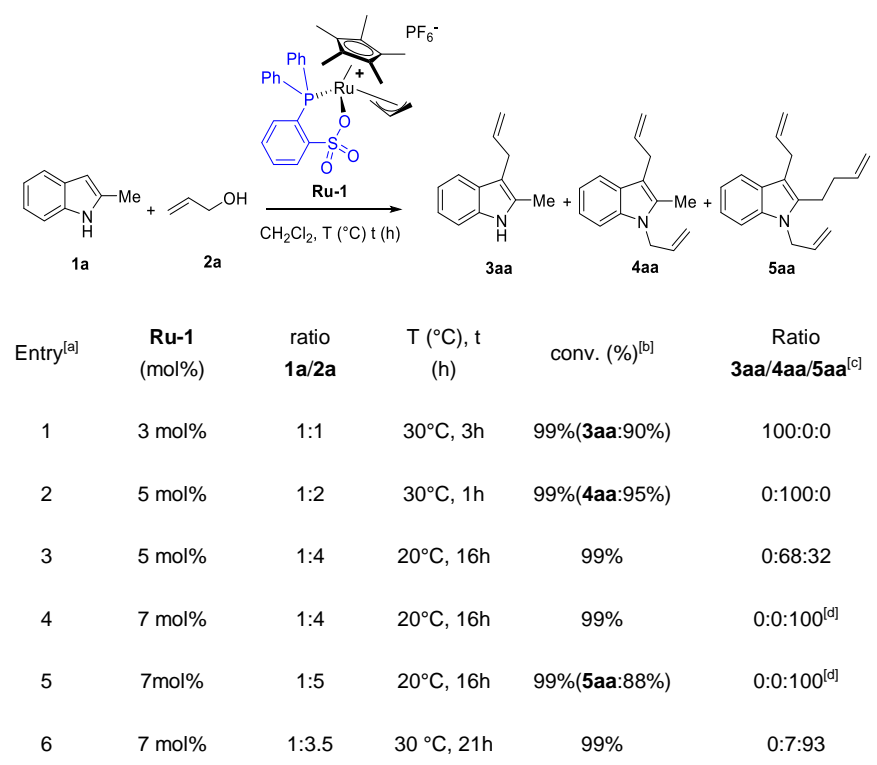

[a] Experimental conditions: all reactions were performed under an inert atmosphere of argon and carried out with allyl alcohol 2a $(0.4-2 \mathrm{mmol}), 2$ methylindole 1a $(0.4 \mathrm{mmol})$, metallic precursor Ru-1 in a closed Schlenk tube in degassed dichloromethane $\mathrm{CH}_{2} \mathrm{Cl}_{2}(0.5 \mathrm{~mL})$. [b] Conversions were determined by $\mathrm{GC}$ and numbers in parentheses correspond to the isolated yield of the major product after column chromatography. [c] ratio was determined by GC analysis on the crude reaction mixture. [d] traces of tetra-allylated product was detected. branched compounds between 70 and $96 \%$ isolated yields. Interestingly, reverse prenylation was also observed starting from 2-Methyl-3-buten-2-ol 2 f affording allylated indole 3af in up to $93 \%$ isolated yield. ${ }^{[21]}$ The reaction of $\mathbf{1 a}$ with linear allylic alcohol $\mathbf{2 g}$ and $\mathbf{2 h}$ provided the access to the branched indoles 3ab and 3ad in up to $97: 3$ ratio. In the light of the selective formation of branched products, the diallylation reaction provided the access to the dibranched indoles 4 with isolated yields ranging from 86 and $99 \%$ without diastereoselectivity. Interestingly, as a reminiscence of the Potier statements, during the isolation by column chromatography on silica gel of the colourless indole 3aa, we observed its partial decomposition highlighted by the apparition of a yellow band..$^{[1 c]}$ Analysis of the side product demonstrated the formation of the fluorescent pseudoindoxyl 6aa. The latter arose from the oxidation of the indole 3aa involving the transient formation of hydroperoxides followed by a semi pinacolic rearrangement. ${ }^{[8,22]}$ Thus, having prepared our set of substituted indoles, we next examined their reactivity toward oxidation. To achieve this task, solvent less oxidation of the suspended indole $3 \mathrm{ac}$ on $\mathrm{SiO}_{2}$ was chosen to prevent the formation of undesired side products arising intermolecular side reactions (Table 2). ${ }^{[8]}$ To our delight, $20 \%$ of conversion was observed after one hour under sun light (entry 1 ). It is important to note that shorter reaction time, highlighted the transient formation of the putative hydroxyindolenine intermediates as a diastereoisomeric mixture which were detected by $\mathrm{GC} / \mathrm{MS}$ and ${ }^{1} \mathrm{H}$ NMR. ${ }^{[8 d, 23]}$ Longer reaction time improved the conversion and almost exclusive formation of the 3-oxindole 6ac was obtained after three-day reaction time (entry 4). Reaction time can be shortened and

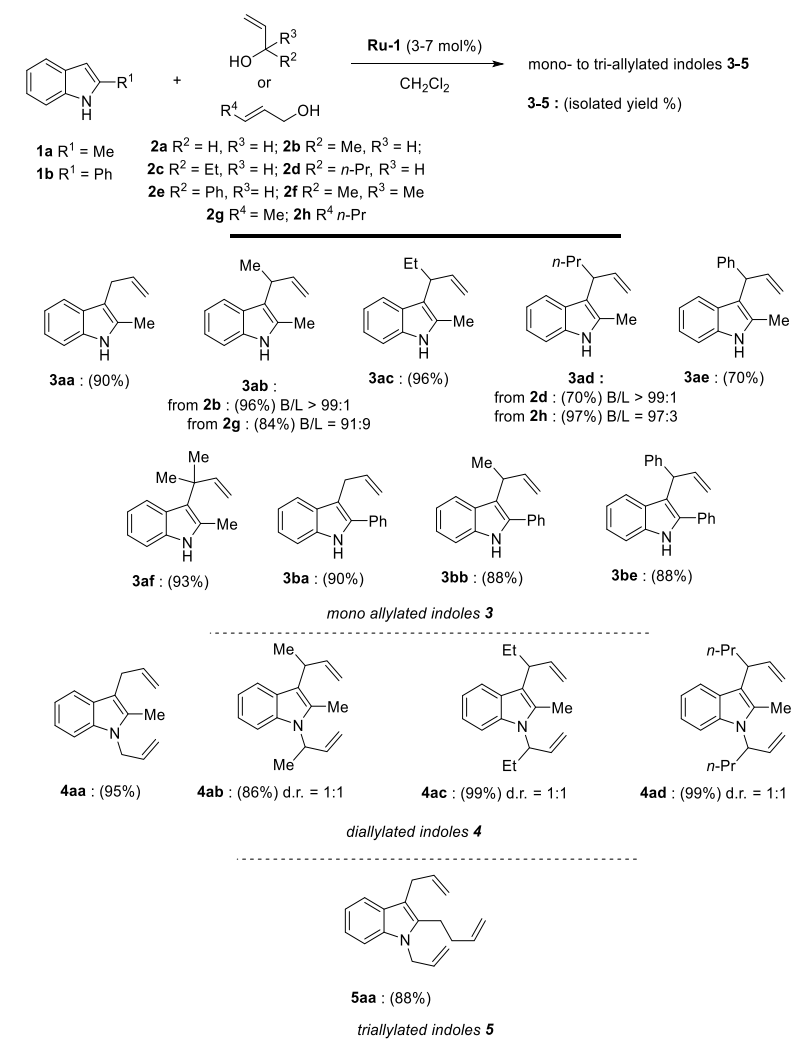

Scheme 1. Regio- and Site-selective allylation of 2-substituted indoles 1. 
when similar reaction was performed under UV irradiation $(\lambda=$ $312 \mathrm{~nm}$ ) product 6ac was obtained in less than five hours with up to $71 \%$ of isolated yield (entry 7 ). The reaction rate was greatly affected by the presence of the $\mathrm{N}-\mathrm{H}$ moiety. Using similar protocol, the $\mathrm{N}$-substituted indole 4 aa provided less than $10 \%$ of the corresponding oxindoles after one-week reaction time. ${ }^{[9]]}$ As expected, owing to their higher oxidation potential, 2phenylindoles $\mathbf{3 b}(\mathbf{a}, \mathbf{b}, \mathbf{e})$ did not undergo oxidation under these conditions. ${ }^{[8]}$ The semi pinacolic rearrangement was also examined with branched indoles 3ab, 3ac and 3ae (Scheme 2). As a result, no or very low diastereoselectivities were observed with oxindoles $6 \mathbf{a b}$ and $6 \mathbf{a c}$

Table 2. Solid state oxidation of C(3)-allylated indole 3ac.<smiles>CCC1(CC)Nc2ccccc2C1=O</smiles>

$\begin{array}{ccccc}\text { Entry } & \text { Conds. }^{[a]} & \begin{array}{c}6 \mathrm{6ac} / \mathrm{SiO}_{2} \\ (\mathrm{mmol} / \mathrm{g} \mathrm{SiO} 2)\end{array} & \mathrm{t}(\mathrm{h}) & \text { Conv. }{ }^{[b]} \\ 1 & \mathrm{~A} & 0.6 & 1 & 20 \% \\ 2 & \mathrm{~A} & 0.3 & 1 & 22 \% \\ 3 & \mathrm{~A} & 0.3 & 27 & 66 \% \\ 4 & \mathrm{~A} & 0.3 & 72 & 91 \%(73 \%) \\ 5 & \text { B } & 0.3 & 27 & 38 \% \\ 6 & \text { C } & 0.3 & 4.5 & 84 \% \\ 7 & \text { D } & 0.3 & 4.5 & 98(71 \%)\end{array}$

[a] A: Compound 3ac was suspended on $\mathrm{SiO}_{2}$ and the reaction mixture was placed in air at room temperature without stirring. B: Compound 3ac was suspended on $\mathrm{SiO}_{2}$ and the reaction mixture was placed in air at room temperature in the dark without stirring. C: Compound 3ac was suspended on $\mathrm{SiO}_{2}$ and the reaction mixture was placed in air at room temperature under UV irradiation without stirring. D: Compound 3ac was suspended on $\mathrm{SiO}_{2}$ and the reaction mixture was placed in air at room temperature under UV irradiation under stirring. [b] Conversions were determined by ${ }^{1} \mathrm{H}$ NMR. Numbers in parentheses correspond to the isolated yield of the oxindole 6ac after column chromatography.

In contrast, substituted indole 3ae allowed up to $40 \%$ of diastereoisomeric excess. Interestingly, configuration of the major diastereoisomer was unambiguously confirmed by X-ray studies. It is noteworthy that intermolecular $\mathrm{H}$-bonding interactions prevail in solid state and no noticeable $\pi-\pi$ stacking interactions were detected. ${ }^{[24]}$ Oxidation of indole 3aa occurred at faster rate and under a modified procedure, pseudoindoxyl 6aa was obtained in up to $84 \%$ yield. Taking together, the nature of the allylic substituent had a profound impact on the transformation rate and the overall reactivity follows the decreasing order $3 a a>3 a b=3 a c>3 a f>3 a e$.

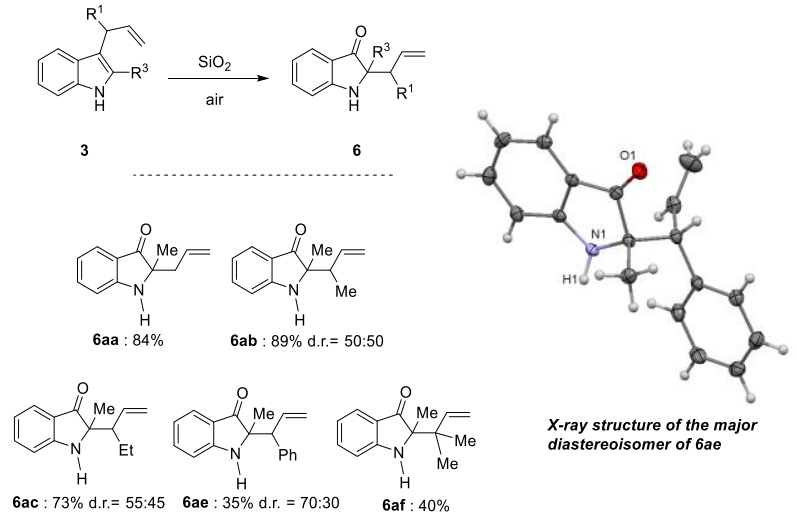

Scheme 2. Solid-state oxidation of the $\mathrm{C}(3)$-allylated indoles 3 over $\mathrm{SiO}_{2}$. X-ray structure of the major diastereoisomer of 6ae. CCDC 1533366 contains the supplementary crystallographic data for $6 \mathbf{a e}$

Keeping in mind, the low reactivity of the disubstituted indoles 4 towards solid state oxidation allowed us to next investigate the possibility of introducing a different second allylic substituent on the nitrogen atom to further perform cyclization through Ring Closing Metathesis (RCM) on the resulting compounds (Scheme 3). As expected, the use of our allylation catalyst Ru-1 led to the expected formation of the corresponding diallylated pseudoindoxyls 7 in $55-98 \%$ isolated yields (Scheme 3). A rapid screening of the reaction conditions demonstrated that Hoveyda-Grubbs II precatalyst allowed the formation of the tricyclic adducts in up to $84 \%$ isolated yields. ${ }^{[9 \mathrm{~m}, 25]}$ Owing to the rigid structure of the tricyclic adducts, diastereoisomers of $\mathbf{8 a b}, \mathbf{a c}, \mathbf{a e}$ were easily separated after isolation by column chromatography.

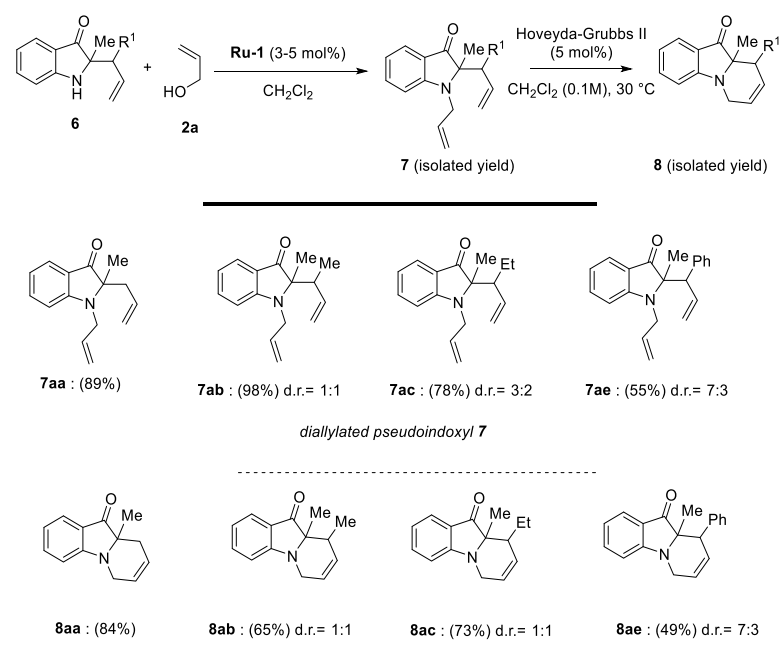

cyclized pseudoindoxyl 8

Scheme 3. Allylation/Metathesis sequence on oxindoles 6 . 

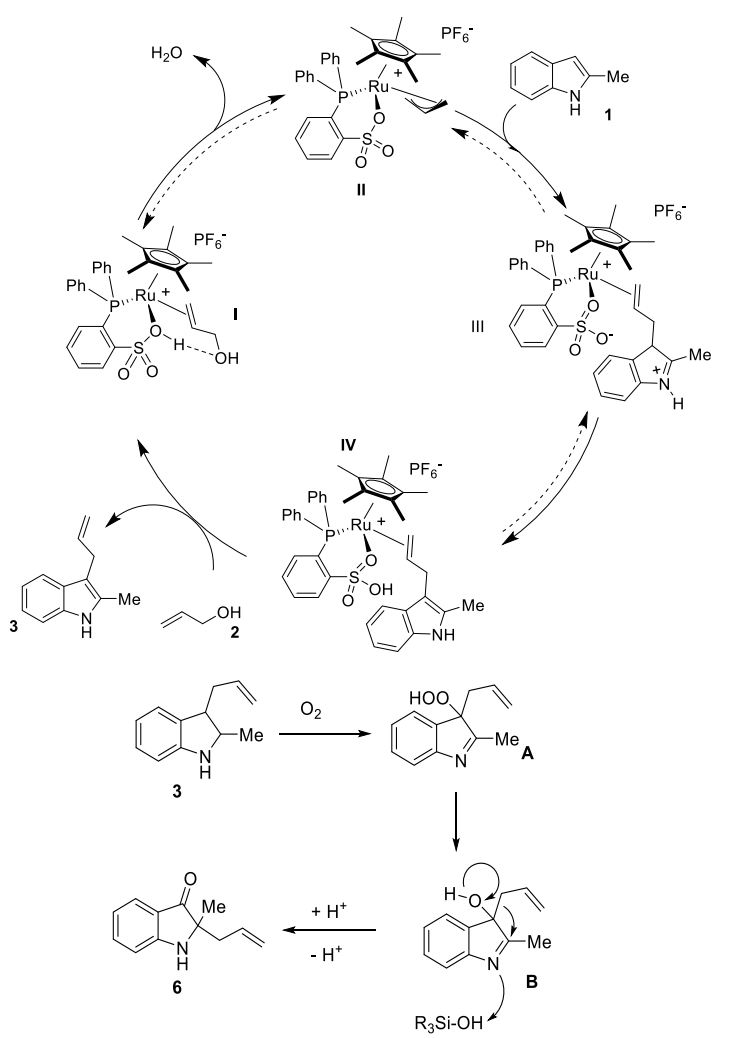

Surface assited semi pinacolic rearrangment

Figure 2. Proposed overall mechanisms.

According to the previous independent reports of Kitamura, ${ }^{[26]}$ Pregosin $^{[27]}$ and us, ${ }^{[19]}$ an overall plausible mechanism for the allylation of indoles $\mathbf{1}$ is depicted in Figure 2. It involves the activation of the allylic alcohol $\mathbf{2}$ by the protonated sulfonate fragment on the ruthenium(II) intermediate I followed by the oxidative addition and the release of a water molecule. Outer sphere approach of the nucleophilic indole 1 on the $\pi$ allylic ruthenium(IV) intermediate II followed by proton transfer and ligand exchange on IV with allylic alcohol $\mathbf{2}$, release the allylated indole $\mathbf{3}$. Concerning the pseudoindoxyls 6 , according to previous reports on 2,3-disubstituted indoles oxidation and related compounds, formation of a hydroperoxide $\mathbf{A}$ tends to be the key intermediate. ${ }^{[4,8 b, c, 28,29 d]}$ Homolysis of this latter followed by reduction via comproportionation with $\mathbf{3}$, water or the surface involving hydroxy radical might explain the formation of hydroxyindolenine B. ${ }^{[29]}$ Finally, the semi pinacol rearrangement of $\mathbf{B}$ assisted by the acidic $\mathrm{R}_{3} \mathrm{SiOH}$ groups led to the formation of the expected pseudoindoxyl 6 .

The photophysical properties of uncyclized and cyclized pseudoindoxyl compounds $7 \mathbf{a a}$ and $8 \mathbf{a a}$ are given in Table 3, and the absorption and emission spectra, measured in dichloromethane and more interestingly in water of 7aa and 8aa are presented in Figure 3. The UV-vis absorption spectra of 7aa and 8aa in dichloromethane display a broad band at $\lambda=407$ and $410 \mathrm{~nm}$, respectively, presenting a shoulder which can be ascribed to an intramolecular charge transfer (ICT) transition. Compounds 7aa and 8aa are also strongly fluorescent in solution at $298 \mathrm{~K}$, with fluorescence quantum yield up to $59 \%$. Solvatochromic and fluorosolvatochromic effects were observed by using two different solvents (Table 3). Interestingly, they exhibit positive fluorosolvatochromism: increasing the polarity of the solvent leads to a red shift (Stock shift $\approx 45 \mathrm{~nm}$ ) of the emission band (for 7aa: $\lambda_{\text {em }}\left(\mathrm{CH}_{2} \mathrm{Cl}_{2}\right)=455 \mathrm{~nm} ; \lambda_{\text {em }}\left(\mathrm{H}_{2} \mathrm{O}\right)=498$ $\mathrm{nm})$, consistent with a more pronounced charge-transfer character due to hydrogen bonding interactions with the oxindole and the molecules of water. ${ }^{[2 b, 23,28]}$ Unlike the absorption spectra, we can notice a shoulder is present at longer wavelength on all the emission spectra in dichloromethane and water for both compounds meaning that the shape of the emission is not affected by the solvent. The effect of the allylic substituent had a minimal incidence of the absorption and emission properties on the resulting tricyclic adducts whereas the quantum yield was reduced by the introduction of the phenyl moiety presumably due to higher vibrational degrees of freedom.

Table 3. Photophysical properties of 7aa, 8aa, 8ab, and 8ae in $\mathrm{H}_{2} \mathrm{O}$ and $\mathrm{CH}_{2} \mathrm{Cl}_{2}$.

$\begin{array}{cccccc}\text { Compound } & \text { Solvent } & \lambda_{\mathrm{abs}} / \mathrm{nm}\left(\boldsymbol{\varepsilon}_{\mathrm{max}}\right)^{[a]} & \lambda_{\text {em }} / \mathrm{nm} & \Phi_{\text {em }}^{[\text {[b] }} & \text { Stokes shift/cm-1 } \\ \text { 7aa } & \mathrm{CH}_{2} \mathrm{Cl}_{2} & 407,420(s h)(4,2 ; 4) & 455,488(s h) & 45 & 2592 \\ \text { 7aa } & \mathrm{H}_{2} \mathrm{O} & 430(3,8) & 498,526(s h) & 59 & 3175 \\ \text { 8aa } & \mathrm{CH}_{2} \mathrm{Cl}_{2} & 410,428(s h)(3,3 ; 2,9) & 458,488(s h) & 47 & 2556 \\ \text { 8aa } & \mathrm{H}_{2} \mathrm{O} & 431(3,9) & 500,534(s h) & 42 & 3201 \\ \text { 8ab-d1 } & \mathrm{CH}_{2} \mathrm{Cl}_{2} & 409,430(s h)(2.6,2.2) & 457,480(s h) & 59 & 2568 \\ \text { 8ab-d1 } & \mathrm{H}_{2} \mathrm{O} & 425(0.8) & 497,527(s h) & 40 & 3368 \\ \text { 8ab-d2 } & \mathrm{CH}_{2} \mathrm{Cl}_{2} & 410,430(s h)(1.9,1.8) & 460,486(s h) & 56 & 2651 \\ \text { 8ab-d2 } & \mathrm{H}_{2} \mathrm{O} & 434(1.1) & 500,529(s h) & 35 & 3041 \\ \text { 8ae-d1 } & \mathrm{H}_{2} \mathrm{O} & 428(1.0) & 496,524(s h) & 35 & 3203 \\ \text { 8ae-d2 } & \mathrm{H}_{2} \mathrm{O} & 438(2.6) & 501,527(s h) & 29 & 2871\end{array}$

[a] Units $=10^{3} \mathrm{Mol}^{-1} \mathrm{~cm}^{-1}$. [b] Fluorescence quantum yield (\%) with $\pm 10 \%$ error versus quinine sulphate.
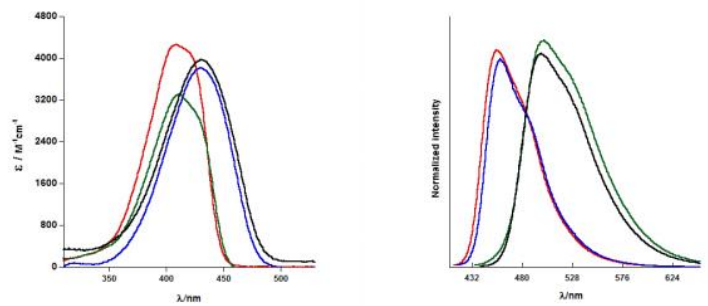

Figure 3. Absorption and Emission spectra of 7 aa in $\mathrm{CH}_{2} \mathrm{Cl}_{2}$ (red), in $\mathrm{H}_{2} \mathrm{O}$ (blue) and of $8 \mathrm{aa}$ in $\mathrm{CH}_{2} \mathrm{Cl}_{2}$ (green), in $\mathrm{H}_{2} \mathrm{O}$ (black).

\section{Conclusions}

In conclusion, through the use of a well-defined m-allylic ruthenium(IV) precatalyst, we achieved the site and regioselective allylation of 2-substituted indoles. Sustainable solid state oxidation under air of the corresponding indoles 3 in the absence of photosensitizer gave the corresponding 3-oxindole 
derivatives. This reaction sequence releasing only water as side product provides a promising alternative to the use of strong oxidant. Finally, solid state oxidation in the presence of photosensitizer would provide interesting results to reluctant substrates.

\section{Acknowledgements}

H. L. thanks the MESRI-Ministère de l'Enseignement Supérieur, de la Recherche et de I'Innovation for fellowship.

Keywords: ruthenium - allylation • oxidation $\cdot$ metathesis • fluorescence

[1] Aristotelone : a) D. Stoermer and C. H. Heatcock, J. Org. Chem. 1993 58, 564; Brevianamide : b) R. M. Williams, T. Glinka, E. Kwast, H. Coffman and J. K. Stille, J. Am. Chem. Soc.1990, 112, 808; Mytraginine : c) G. M. T. Robert, A. Ahond, C. Poupat, P. Potier, H. Jacquemin, S. K. Kan, J. Nat. Prod. 1983, 46, 708; d) H. Takayama, H. Ishikawa, M. Kurihara, M. Kitajima, N. Aimi, D. Ponglux, F. Koyama, K. Matsumoto, T. Moriyama, L. T. Yamamoto, K. Watanabe, T. Murayama, S. Horie, J. Med. Chem. 2002, 45, 1949; Isatisine: e) J.-F. Liu, Z.-Y. Jiang, R.-R. Wang, Y.-T. Zeng, J.-J. Chen, X.-M. Zhang and Y.-B. Ma Org. Lett. 2007, 9, 4127; Duocarmycin : f) T. Yasuzawa, Y. Saitoh, M. Ichimura, I. Takahashi and H. Sano, J. Antibiot. 1991, 44, 445; g) K. Yamada, T. Kurokawa, H. Tokuyama and T. Fukuyama, J. Am. Chem. Soc. 2003, 125, 6630; Fluorocurine : h) D. D. O'Rell, F. G. H. Lee, V. Boekelheide, J. Am. Chem. Soc. 1972, 94, 3205; Austamide : i) P. S. Baran and E. J. Corey, J. Am. Chem. Soc. 2002, 124, 7904;

[2] a) V. F. Ximenes, A. Campa and L. H. Catala, ni, Arch. Biochem. Biophys. 2001, 387, 173; b) S. Matsumoto, D. Samata, M. Akazome, K. Ogura, Tetrahedron Lett. 2009, 50, 111; c) J. H. Lee, J.-H. So, J. H. Jeon, E. B. Choi, Y.-R. Lee, Y.-T. Chang, C.-H. Kim, M. A. Bae, J. H. Ahn, Chem. Commun. 2011, 47, 7500; d) H.-S. Chun, J. H. Jeon, H. S Pagire, J. H. Lee, H.-C. Chung, M. J. Park, J.-H. So, J.-H. Ryu, C.-H. Kim, J. H. Ahn, M. A. Bae, Mol. BioSyst., 2013, 9, 630

[3] W. H. Perkin and S. G. P. Plant, J. Chem. Soc. Trans. 1923, 123, 676.

[4] a) B. Witkop, J. Am. Chem. Soc. 1950, 72, 614; b) J. B. Patrick and B. Witkop, J. Am. Chem. Soc. 1950, 72, 633.

[5] X. Zhang and C. S. Foote, J. Am. Chem. Soc. 1993, 115, 8867.

[6] a) M. J. Buller, T. G. Cook and Y. Kobayashi, Heterocycles 2007, 72, 163; b) K. Higuchi, Y. Sato, S. Kojima, M. Tsuchimochi, K. Sugiura, M. Hatori, T. Kawasaki, Tetrahedron 2010, 66, 1236; c) A. Karadeolian and M. A. Kerr, Angew. Chem. Int. Ed. 2010, 49, 1133; d) Q. Yin, S.-L. You, Chem. Sci. 2011, 2, 1344; e) H. Ikemoto, R. Tanaka, K. Sakata, M. Kanai, T. Yoshino, S. Matsunaga, Angew. Chem. Int. Ed. 2017, 56, 7156 ;

[7] a) H. Wang, J. Cai, X. Ji, F. Xiao, Y. Chen, G.-J. Deng, Angew. Chem. Int. Ed. 2016, 55, 307; b) M. Movassaghi, M. A. Schmidt, J. A. Ashenhurst, Org. Lett. 2008, 10, 4009; c) J.-G. Rodriguez and A. San Andrès, J. Heterocyclic Chem. 1991, 28, 1293.

[8] a) C. A. Mateo, A. Urrutia, J. G. Rodríguez, I. Fonseca, F. H. Cano, J. Org. Chem. 1996, 61, 810; b) S. Lerch, L.-N. Unkel, M. Brasholz, Angew. Chem. Int. Ed. 2014, 53, 6558; c) W. Ding, Q.-Q. Zhou, J. Xuan, T.-R. Li, L.-Q. Lu, W.-J. Xiao, Tetrahedron Lett. 2014, 55, 4648; d) E. Schendera, S. Lerch, T. von Drathen, L.-N. Unkel, M. Brasholz, Eur. J. Org. Chem. 2017, 2017, 3134.

[9] Miscellaneous transformations leading to pseudo indoxyls: a) $Y$. Liu, W. W. McWorther Jr. J. Am. Chem. Soc. 2003, 125, 4240; b) Y. Liu W. W. McWhorther, J. Org. Chem. 2003, 68, 2618 ; c) B. Lu, Y. Luo, L. Liu, L. Ye, Y. Wang, L. Zhang, Angew. Chem. Int. Ed. 2011, 50, 8358; d) K. Okuma, N. Matsunaga, N. Nagahora, K. Shioji and Y. Yokomori,
Chem. Commun. 2011, 47, 5822; e) A. Wetzel and F. Gagosz, Angew. Chem. Int. Ed. 2011, 50, 7354; f) J. L. Rogers, J. B. MacMillan, J. Am Chem. Soc. 2012, 134, 12378; g) A. Parra, R. Alfaro, L. Marzo, A Moreno-Carrasco, J. L. García Ruano and J. Alemán, Chem. Commun. 2012, 48, 9759; h) J. Kim, J. S. Schneekloth, E. J. Sorensen, Chem. Sci. 2012, 3, 2849; i) Y. Goriya and C.V. Ramana, Chem. Commun 2013, 49, 6376; j) Y.-L. Zhao, Y. Wang, J. Cao, Y.-M. Liang, P.-F. Xu, Org. Lett. 2014, 16, 2438; k) C. V. Suneel Kumar, C. V. Ramana, Org Lett. 2015, 17, 2870; I) Y. Shao, Y.-M. Zeng, J.-Y. Ji, X.-Q. Sun, H.-T. Yang, C.-B. Miao, J. Org. Chem. 2016, 81, 12443; m) K. Dhara, T. Mandal, J. Das, J. Dash, Angew. Chem. Int. Ed. 2015, 54, 15831; n) Z. Xia, J. Hu, Y.-Q. Gao, Q. Yao, W. Xie, Chem. Commun. 2017, 53, 7485.

[10] a) Comprehensive Organic Synthesis, Vol. 4 (Eds.: S. A. Godleski, B. M. Trost, I. Fleming), Pergamon, New York, 1991, pp. $585-661$; b) J. Tsuji, Transition Metal Reagents and Catalysts: Innovations in Organic Synthesis, Wiley, Chichester, 2000, p. 109; c) B. M. Trost and M. L. Crawley, Chem. Rev. 2003, 103, 2921; d) G. Helmchen, A. Pfaltz, Acc. Chem. Res. 2000, 33, 336.

[11] Selected references: a) T. Kondo, H. Ono, N. Satabe, T. Mitsudo and $Y$ Watanabe, Organometallics 1995, 14, 1945; b) B. M. Trost, P. L. Fraisse and Z. T. Ball, Angew. Chem. Int. Ed. 2002, 41, 1059; c) C. Bruneau, J.-L. Renaud and B. Demerseman, Chem. Eur. J. 2006, 12, 5178; d) M. Kawatsura, F. Ata and T. Itoh, Chem. Commun. 2007, 4283; e) K. Onitsuka, H. Okuda and H. Sasai, Angew. Chem. Int. Ed. 2008, 47, 1454; f) H.-J. Zhang, B. Demerseman, L. Toupet, Z. Xi and C Bruneau, Adv. Synth. Catal. 2008, 350, 1601; g) A. Bayer, U. Kazmaier Org. Lett. 2010, 12, 4960; h) Z. Sahli, N. Derrien, S. Pascal, B. Demerseman, T. Roisnel, F. Barrière, M. Achard and C. Bruneau, Dalton Trans. 2011, 40, 5625; i) M. Kawatsura, M. Sato, H. Tsuji, F. Ata, T. Itoh, J. Org. Chem. 2011, 76, 5485; j) K. Takii, N. Kanbayashi, K. Onitsuka, Chem. Commun. 2012, 48, 3872; k) B. M. Trost, M. Rao, A. P. Dieskau, J. Am. Chem. Soc. 2013, 135, 18697; I) X. Zhang, W.-B. Liu, Q.-F. Wu, S.-L. You, Org. Lett. 2013, 15, 3746; m) M. Kawatsura, K. Uchida, S. Terasaki, H. Tsuji, M. Minakawa and T. Itoh, Org. Lett., 2014, 16, 1470; n) T. Shinozawa, S. Terasaki, S. Mizuno and M. Kawatsura, J. Org. Chem. 2014, 81, 5766; o) A. Bayer and U. Kazmaier, J. Org. Chem. 2014, 79, 84, 91; p) A. Bayer and U. Kazmaier, Chem. Eur. J. 2014, 20, 10484; q) Z.-P. Yang, C.-X. Zhuo and S.-L. You, Adv. Synth. Catal. 2014, 356, 1731; r) N. Kanbayashi, K. Hosoda, M. Kato, K. Takii, T.-a. Okamura, K. Onitsuka, , Chem. Commun. 2015, 51, 10895; s) N. Kanbayashi, A. Yamazawa, K. Takii, T.-a. Okamura, K. Onitsuka, Adv Synth. Catal. 2016, 358, 555;

[12] For recent reviews on allylic substitution with allylic alcohols : a) B. Sundararaju, M. Achard, C. Bruneau, Chem. Soc. Rev. 2012, 41, 4467; b) A. Lumbroso, M. L. Cooke, B. Breit, Angew. Chem. Int. Ed. 2013, 52, 1890; c) N. A. Butt and W. Zhang, Chem. Soc. Rev. 2015, 44, 7929; d) M. Dryzhakov, E. Richmond, J. Moran, Synthesis 2016, 48, 935;

[13] Selected recent references for Iridium a) M. Lafrance, M. Roggen, E. M. Carreira, Angew. Chem. Int. Ed. 2012, 51, 3470; b) M. Roggen, E. M. Carreira, Angew. Chem. Int. Ed. 2012, 51, 8652; c) X. Zhang, L. Han, S.-L. You, Chem. Sci. 2014, 5, 1059; d) X. Liang, K. Wei, Y.-R. Yang, Chem. Commun. 2015, 51, 17471.

[14] Selected recent references for Palladium: a) D. Banerjee, R. V. Jagadeesh, K. Junge, H. Junge, M. Beller, Angew. Chem. Int. Ed. 2012, 51, 11556; b) Z.-L. Tao, W.-Q. Zhang, D.-F. Chen, A. Adele, L.-Z. Gong, c) Y. Gumrukcu, B. de Bruin, J. N. H. Reek, ChemSusChem 2014, 7, 890; d) X. Huo, G. Yang, D. Liu, Y. Liu, I. D. Gridnev, W. Zhang, Angew. Chem. Int. Ed. 2014, 53, 6776; e) K. A. Ostrowski, D. Vogelsang, A. J. Vorholt, 2016, 6, 1302; f) F.-P. Wu, J.-B. Peng, L.-Y. Fu, X. Qi and X.-F. Wu, Org. Lett. 2017, 19, 5474; g) J. Jing, X. Huo, J. Shen, J. Fu, Q. Meng, W. Zhang, Chem. Commun. 2017, 53, 5151; h) S. Akkarasamiyo, S. Sawadjoon, A. Orthaber and J. S. M. Samec, Chem. Eur. J. 2018, DOI: $10.1002 /$ chem.201705164.

[15] Selected recent references for Nickel : a) Y. Kita, H. Sakaguchi, Y Hoshimoto, D. Nakauchi, Y. Nakahara, J.-F. Carpentier, S. Ogoshi, K. 
Mashima, Chem. -Eur. J. 2015, 21, 14571; b) Y. Kita, R. D. Kavthe, H. Oda, K. Mashima, Angew. Chem. Int. Ed. 2016, 55, 1098.

[16] Selected references for Ruthenium: a) H. Saburi, S. Tanaka, M. Kitamura, Angew. Chem. Int. Ed. 2005, 44, 1730; b) S. Tanaka, H. Saburi, M. Kitamura, Adv. Synth. Catal. 2006, 348, 375; c) A. B. Zaitsev S. Gruber, P. S. Pregosin, Chem. Commun. 2007, 4692; d) I. F. Nieves, D. Schott, S. Gruber, P. S. Pregosin, Helv. Chim. Acta 2007, 90, 271; e) S. Gruber, A. B. Zaitsev, M. Wörle, P. S. Pregosin, Organometallics 2008, 27, 3796; f) S. Tanaka, T. Seki, M. Kitamura, Angew. Chem. Int. Ed. 2009, 48, 8948; g) J. A. van Rijn, M. Lutz, L. S. von Chrzanowski, A L. Spek, E. Bouwman, E. Drent, Adv. Synth. Catal. 2009, 351, 1637; h) A. B. Zaitsev, H. F. Caldwell, P. S. Pregosin and L. F. Veiros, Chem. Eur. J. 2009, 15, 6468; i) J. A. van Rijn, M. A. Siegler, A. L. Spek, E. Bouwman, E. Drent, Organometallics 2009, 28, 7006; j) B. Sundararaju, M. Achard, B. Demerseman, L. Toupet, G. V. M. Sharma, and C. Bruneau, Angew. Chem. Int. Ed. 2010, 49, 2782; k) K. Miyata, M. Kitamura, Synthesis 2012, 44, 2138; I) Y. Suzuki, T. Seki, S. Tanaka, M. Kitamura, J. Am. Chem. Soc. 2015, 137, 9539; m) S. Tanaka, R. Gunasekar, T. Tanaka, Y. lyoda, Y. Suzuki, M. Kitamura, J. Org. Chem. 2017, 82, 9160.

[17] S. Bähn, S. Imm, K. Mevius, L. Neubert, A. Tillack, J. M. J. Williams and M. Beller, Chem. Eur. J. 2010, 16, 3590.

[18] a) F. A. Cruz, Y. Zhu, Q. D. Tercenio, Z. Shen and V. M. Dong, J. Am. Chem. Soc. 2017, 139, 10641; b) K. Xu, T. Gilles and B. Breit, Nat. Commun. 2015, 6, 7616.

[19] F. Jiang, M. Achard, and C. Bruneau, Synthesis and Applications in Catalysis of Metal Complexes with Chelating Phosphinosulfonate Ligands. In Advances in Organometallic Chemistry; Perez, P. J, Ed.; Academic Press: Burlington, 2014; Vol.' 62, pp 159- 218.

[20] a) J. E. Macor, K. Ryan and M. E. Newman, J. Org. Chem. 1989, 54, 4785; b) S. Inagaki, Y. Nishizawa, T. Sugiura and H. Ishihara, J. Chem. Soc. Perkin Trans. 1 1990, 179 c) B. Joseph, O. Cornec and J. -Y. Mérour, Tetrahedron 1998, 54, 7765; d) M. V. Basaveswara Rao, J. Satyanarayana, H. Ila and H. Junjappa, Tetrahedron Lett. 1995, 36, 3385; e) I. Coldham, B. C. Dobson, S. R. Fletcher and A. I. Franklin Eur. J. Org. Chem. 2007, 2676; f) P. A. Suryavanshi, V. Sridharan and
J. C. Menéndez, Org. Biomol. Chem. 2010, 8, 3426; g) Y. -C. Xiao, Q. Q. Zhou, L. Dong, T. -Y. Liu And Y.-C. Chen, Org. Lett. 2012, 14, 5940.

[21] For reverse prenylation see : a) I. Usui, S. Schmidt, M. Keller, B. Breit, Org. Lett. 2008, 10, 1207; b) S. Gruber, A. B. Zaitsev, M. Wörle, P. S. Pregosin and L. F. Veiros, Organometallics 2008, 27, 3796; c) J. Ruchti, E. M. Carreira, J. Am. Chem. Soc. 2014, 136, 16756; d) B. M. Trost, W. H. Chan and S. Malhotra, Chem. Eur. J. 2017, 23, 4405.

[22] For recent oxyfunctionalization process involving hydroperoxide see: a) J. Turconi, F. Griolet, R. Guevel, G. Oddon, R. Villa, A. Geatti, M. Hvala, K. Rossen, R. Göller and A. Burgard, Org. Process Res. Dev. 2014, 18, 417; b) D. M. Schultz, F. Lévesque, D. A. DiRocco, M. Reibarkh, Y. Ji, L. A. Joyce, J. F. Dropinski, H. Sheng, B. D. Sherry and I. W. Davies, Angew. Chem. Int. Ed., 2017, 56, 15274.

[23] F. Kolundzic, M. N. Noshi, M. Tjandra, M. Movassaghi, S. J. Miller, J. Am. Chem. Soc. 2011, 133, 9104.

[24] N. Wyrembak, A. D. Hamilton, J. Am. Chem. Soc. 2009, 131, 4566;

[25] S. B. Garber, J. S. Kingsbury, B. L. Gray, A. H. Hoveyda, J. Am. Chem Soc. 2000, 122, 8168 .

[26] S. Tanaka, H. Saburi, T. Murase, M. Yoshimura and M. Kitamura, J. Org. Chem. 2006, 71, 4682.

[27] S. Gruber, A. B. Zaitsev, M. Wörle and P. S. Pregosin, Organometallics 2009, 28, 3437

[28] D. I. Pattison, A. S. Rahmanto and M. J. Davies, Photochem. Photobiol. Sci. 2012, 11, 38.

[29] a) I. Saito and T. Matsuura, Acc. Chem. Res. 1977, 10, 346; b) M. Nakagawa, H. Yamaguchi and T. Hino, Tetrahedron Lett. 1970, 47, 4035; c) A. Coste, G. Karthikeyan, F. Couty and G. Evano, Synthesis 2009, 17, 2927; d) X. Shen, J. Lind, T. E. Eriksen and G. Merényi, J. Chem. Soc. Perkin Trans 2 1990, 597; e) M. Ehrenshaft, L. J. Deterding and R. P. Mason, Free Radic. Biol. Med. 2015, 89, 220; f) S. E. Lehman, A. S. Morris, P. S. Mueller, A. K. Salem, V. H. Grassian and S. C. Larsen, Environ. Sci.: Nano 2016, 3, 56; g) B. Fubini and H. Hubbard, Free Radic. Biol. Med. 2003, 34, 1507.

[30] L. Wang, Y. Shen, M. Yang, X. Zhang, W. Xu, Q. Zhu, J. Wu, Y. Tian and H. Zhou, Chem. Commun. 2014, 50, 8723. 
Entry for the Table of Contents (Please choose one layout)

Layout 1:

\section{COMMUNICATION}

Preparation of tricyclic pseudoindoxyls was easily achieved from allylic alcohols and indoles generating water and ethylene as the only side products.

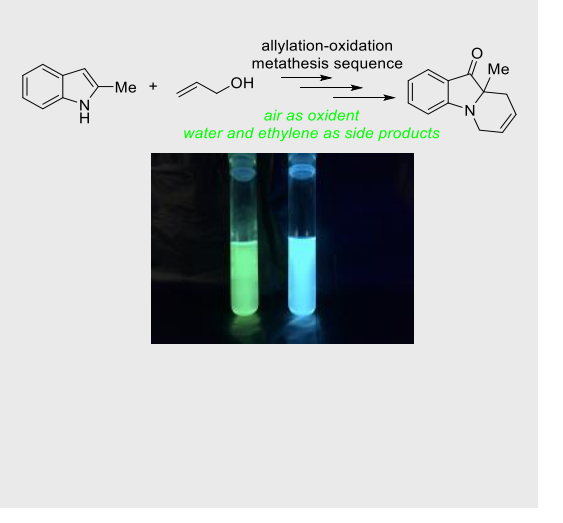

Hortense Lauwick, Yang Sun, Huriye Akdas-Kilig, Sylvie Dérien* and Mathieu Achard* $^{*}$

Page No. - Page No.

Access to 3-oxindoles from Allylic Alcohols and Indoles 